\title{
The World Turned Inside Out: Revolutions of the Infinite Sphere from Hermes to Pascal
}

\section{MICHAEL H. KEEFER}

In a text of the twelfth century attributed to the legendary Egyptian sage Hermes Trismegistus, the Liber XXIV philosophorum, one of the twenty-four different answers offered to the question Quid est Deus? is the following: "Deus est sphaera infinita, cuius centrum est ubique, circumferentia nusquam" ("God is an infinite sphere whose centre is everywhere, and whose circumference nowhere"). ${ }^{1}$ The sphere, a traditional image of perfect intelligibility, would seem to be given by this proposition an unintelligible form - a paradox that is heightened by Alain de Lille's revision of the formula later in the same century: "Deus est sphaera intelligibilis cujus centrum ubique, circumferentia nusquam." But as Alain makes clear, "intelligible" here also means unimaginable. A "sphaera corporalis" - Alain seems to be thinking of both the geometrical form and the structure of the cosmos - has a motionless centre and a mobile circumference. However, the centre of this "intelligible sphere," the created individual, is mobile, and the motion of the centre is caused by God, the unmoved mover. ${ }^{2}$

Although Alain "warns against any appeal to the imagination, ${ }^{33}$ one can hardly avoid speculating as to what may be implied by this paradox, which in his first formulation seems to be an image of the deity alone, but which becomes in his commentary an expression of the relation between the created individual and the Creator. The image, then, conveys the notion of an indeterminate but somehow constant relationship between divine immanence (the ubiquitous centre) and transcendence (the unlocatable circumference), or between the insignificant created individual that is the centre point, and the inconceivable immensity of the divine whole. Given the 
multiplicity of such centres, is one to understand this intelligible sphere (in a not-quite Platonic sense) as sphaeritas, the aggregate form of all possible spheres centred on create individuals? Or is it to be thought of rather as a limitless expansion of a "corporeal" sphere, to the extent that the infinitesimal centre becomes ubiquitous and the circumference escapes altogether from the category of space? One passage from Alain's text may suggest a third possibility. "In the corporeal sphere," he writes, "the centre, because of its smallness, can hardly be said to be anywhere: the circumference however is taken to be in many places. But in the intelligible sphere, the centre is everyhere, the circumference nowhere." 4 In these sentences, the attributes of centre and circumference are effectively exchanged, becoming absolute in the process. One might speak, then, of a topological inversion in which centre and circumference change roles. In a strange figure of chiasmus, the centre becomes a metonymy for the circumference, and the circumference a metonymy for its own centre: the corporeal sphere is turned inside out.

It may legitimately be doubted that such a conclusion was intended by Alain de Lille in the late twelfth century. But a topological inversion is certainly implicit five centuries later in Blaise Pascal's description of nature as "une sphère infinie dont le centre est partout, la circonférence nulle part." In impressing upon his reader a sense of the infinitude that surrounds her, such that "nous avons beau enfler nos conceptions au-delà des espaces imaginables, nous n'enfantons que des atomes au prix de la réalité des choses," Pascal is inviting the reader to take herself as the centre. He then discloses within this centre a second abyss of the infinitely small, within which appears "une infinité d'univers, dont chacun a son firmament, ses planètes, sa terre, en la même proportion que le monde visible...." 5 The paradox, understood as a topological inversion that makes every possible centre into an unlocatable circumference as well, applies both to nature as a whole and to everything within it, including the reader.

In formulating this physical version of the Hermetic paradox, Pascal wished to expose the dogmatic arrogance of such philosophical titles as Descartes' Des principes de la philosophie or the only apparently more blatant De omni scibili of Giovanni Pico. ${ }^{6}$ His spatial paradox imposes a form of contextualist scepticism - structurally analogous, in certain respects, to the "de-centring" scepticism advanced in recent years by Jacques Derrida ${ }^{7}$ which makes the very notion of knowable first principles or origins seem absurd, and which would oblige a book about All That Can Be Known to be 
a very slim volume indeed. Pascal writes that "On se croit naturellement bien plus capable d'arriver au centre des choses que d'embrasser leur circonférence...." But any apparent philosophical first principle, any simple nature or point of origin, is also a double threshold between two infinities, and therefore no starting point at all. It would, he says, take the same infinite capacity to reach nothingness that it would take to comprehend the whole. The two extremes of infinite immensity and smallness "se touchent et se réunissent à force de s'être éloignées et se retrouvent en Dieu, et en Dieu seulement."8

Looking forward in time, one might remark that the lesson Pascal draws from this - "Nous sommes quelque chose et ne sommes pas tout... $\mathrm{Ne}$ cherchons donc point d'assurance et de fermeté" - has recently been repeated, in a rather different context, by John Austin: "Enough is enough, enough isn't everything."9 But looking back beyond Pascal to the fifteenth century, one might equally well say that the whole passage reads very much like a finely compressed re-interpretation of certain motifs developed in Nicholas of Cusa's De docta ignorantia.

Cusanus, too, denies the possibility of locating any physical centre. From his paradoxical principle of the coincidence of opposites, it follows that the centre of the universe would have to coincide with its circumference - and that the universe therefore has neither centre nor circumference. Applied on any other basis, he suggests, these geometrical terms are unintelligble. For if the universe had a centre, it would also have a circumference. It would thus have within itself its own beginning and end, and would be bounded by something else; there would thus have to be a locus outside the universe - and these, he says, are notions "devoid of all truth." This argument, reminiscent of Lucretius' proof of the spatial infinitude of the cosmos, leads to the conclusion that God, being equidistant from all points, is the centre - and at the same time the circumference. ${ }^{10}$ But while the minimum and the maximum are thus one - as Cusanus writes elsewhere, the centre, diameter and cirumference of an infinite circle are the same (De docta ignorantia, I.xxi) - it is impossible either to descend to the minimum or to ascend to the maximum (Ibid., II.i). Cusanus anticipates Pascal in making the Hermetic paradox express both the structure of the physical universe and the relation of this structure to the divine. ${ }^{11}$ As with Pascal, moreover, his use of this paradox subjects the quest for knowledge to a radical contextualization. The relation of all terms to an absolute minimum-maximum, while guaranteeing their ultimate coherence, also introduces into all 
comparisons, even the most simple, an element of incommensurability: knowledge is thus relative and asymptotic, but never certain, except in mathematics. ${ }^{12}$

While these broad similarities are enough to suggest a connection of some kind between the texts of Cusanus and Pascal, the differences between them are equally striking. Pascal's contemplation of the two infinities is tinged with a vertiginous horror. "Le silence de ces espaces infinis m'effraie."13 But Cusanus is protected from this kind of vertigo by the fact that for him the universe is not absolutely infinite - that is true only of God - but rather indefinite in size: "...it is not infinite; nevertheless, it cannot be conceived as finite, since it has no limits between which it can be enclosed." $14 \mathrm{He}$ writes in De mente that there is a limit to the multiplicity of things, although we do not know that limit; and similarly, while to the mind things appear to be infinitely divisible, any actual process of division would finally encounter the atom, "a quantity which its smallness renders effectively indivisible."15 This atomism puts us in touch with a universal, an originating concept of unity: "One and the same point is in all atoms, just as one and the same whiteness is in all white things." Moreover, "in the point the mind intuits all largeness, and in the centre it intuits the circle."16

Giordano Bruno, echoing the words of Cusanus, was to write with some complacency that "If point does not differ from body, centre from circumference, finite from infinite, maximum from minimum, we can securely declare that the universe is all centre, or that the universe's centre is everywhere and the circumference nowhere insofar as it differs from the centre - or rather the circumference is everywhere, but the centre is not to be found insofar as it differs from it." This prospect means for him that "all things concur in a perfect unity" - from which follows, quite naturally, the exhortation: "See how we should not afflict our spirit. See how there is nothing that should alarm us." 17 But it is, quite precisely, nothing that does alarm Pascal. His first infinity is a void, in comparison to which our most inflated conceptions of enormity are mere atoms. And if the circuit of our experience is an atom within an atom, the vertiginous counter-turn of Pascal's topological inversion shows any point of apparent plenitude to be itself permeated by abyss upon abyss of emptiness, of absence.

The overtones of confidence, of exaltation even, that pervade Cusanus', and later Bruno's, deployment of the Hermetic paradox thus form a striking contrast to the fear expressed by Pascal. But beneath this difference lie others. Thanks perhaps to the invention of the microscope, Pascal's abyss of the 
infinitely small acquires in his text a strong physical actuality. In Cusanus' writing, on the contrary, it is evident that the dominant category is not physical reality but the mind that measures and divides it. Indeed, he says explicitly that "with respect to us, the plurality of things comes from our thought." 18 What Paul-Henri Michel wrote of Bruno might equally well be applied to Cusanus: "He sought the universe first of all within himself, and it was there that he found it; the receding horizons of an inner abyss having offered him the first view of that which is boundless and formless." 19 But in de-centring and relativizing the universe, Cusanus did not also de-centre himself.

Ernst Cassirer wrote, long since, a penetrating analysis of Cusanus' thought in which he argued that the distinctive feature of his speculations was a recovery of the Platonic concepts of chorismos and methexis, of separation and participation. The recognition that there can be no definite relation between the finite and the infinite shears away the hierachies of mediations and emanations developed by Aristotelian and Neoplatonic thought; the complementary notion of participation allows the finite and conditioned object to point to the ungraspable otherness that gives it form. One might perhaps say that in thinking the Hermetic paradox - which, as reshaped by Cusanus, itself gives enigmatic form to the dialectic of chorismos and methexis - the mind is, in a sense, reflecting its own microcosmic participation in the divine, and its own analogous nature as a containing centre. This, or something similar, appears to be what Cassirer meant when, in commenting on Cusanus' De pace fidei, he wrote that "Every spiritual being has its own centre within itself. And its participation in the divine consists precisely in this centring, in this indissoluble individuality." 20

Pascal's counter-turn or topological inversion amounts to a second decentring, this time of man himself. For to believe oneself to be "centred" means, to him, to renounce God's help and withdraw from his rule - in effect, to repeat the error of the Fall. In the Penseés, Pascal has God's Wisdom say of man: "Il a voulu se rendre centre de lui-même et indépendant de mon secours. Il s'est soustrait de ma domination et s'égalent à moi par le désir de trouver sa félicité en lui-même je l'ai abandonné à lui...."21

A final difference between Cusanus' and Pascal's deployment of the Hermetic paradox now becomes evident. The former is a foundational gesture, the latter a deconstructive one. Cusanus writes that "the precision of the quiddity of whatsoever thing is unattainable by us except in enigma or figure." 22 This remark is given substance by his use of the Hermetic 


\section{8 / Renaissance and Reformation}

enigma, which provides an outline of his application of the same methodological principles, the same dialectic of complicatio and explicatio, to epistemology, to cosmology and to theology. Elsewhere he defines the mind as "a living measure" which "does everything in order to know itself. But seeking its measure in all things, it finds it only there where all things are one."23 Again, the nature of this quest, and of its goal, are defined by the paradox of centre and circumference. Pascal, on the other hand, is clearly writing not only in opposition to the Archimedean gesture of Descartes' Second Meditation, ${ }^{24}$ but also in opposition to the security of a centred self which is protected from vertigo in a de-centred universe by its own microcosmic relation to the divine centre and circumference, as well as by the grounding of that universe in ultimately indivisible elements.

What is at stake is a matter of origins - or, to be more precise, of originary authority, and hence, ultimately, of institutional power. The only privileged perspective in the structure of thought that Cusanus bequeathed to later Renaissance writers is that in which one realizes that there is no privileged perspective - or rather, that all are equally privileged, and thus are included in a unity that comprehends and transcends them all. The result is a thorough dispersal of originary authority, or, one might equally well say, a transfer of such authority from institutional loci to the autonomous centred self. Cusanus, who speaks of the intellect as being capax dei, ${ }^{25}$ would have agreed with Marsilio Ficino when the later wrote, in his commentary on the Philebus, that "the soul, once it has been instructed in the sciences of other things, recovers natural power and generates itself in itself. For it can fashion its total nature in itself by knowing itself. And the mind [mens] does it even better, because in it is the first knowledge: the most perfect knowledge, and therefore the closest to the thing known." 26

Ernst Cassirer's speculations notwithstanding, it is difficult to perceive any specifically Cusanian influence in the writings of the Florentine Neoplatonists of the latter part of the fifteenth century. Only after the printing of his Opera in 1514 by Lefêvre d'Étaples do clear filiations of influence become perceptible - and then they lead to Agrippa, to Copernicus, to Bruno and Kepler. I would like, nonetheless, to conclude by suggesting that between the centre-circumference paradox which so interested Cusanus, and Giovanni Pico della Mirandola's understanding of a still more common Renaissance commonplace, the notion that man is a microcosm, there may be some connections worth exploring. The macrocosm-microcosm analogy, which expresses in another manner the coincidence of maximum and minimum, 
is of course of primary importance in Cusanus' thought; there is no need to labour its connections to the motif of the infinite sphere. ${ }^{27}$ But it is in Pico that one finds a clear - and yet, I believe, hitherto unappreciated - conflation of the two.

In the Second Proem of his Heptaplus, a sevenfold commentary upon the first chapters of Genesis, and therefore a text concerned throughout with an explicatio of origins, Pico interprets the tabernacle of Moses as a figure of the threefold structure of the geocentric universe. The outer part of the tabernacle, open to the weather, and containing sacrificial animals (and thus an alternation of life and death) as well as men both holy and profane, is an image of the sublunary world. Within it is the sanctuary, with its seven-branched candelabra, which is an image of the seven planets and the celestial world. Inside this there is the inner sanctuary, the Holy of Holies, in which are the ark of the covenant and the winged cherubim - an image of the supercelestial world. 28

The whole structure is an inverse metonymy of the universe. The outer part effectively 'contains' the sublunary world which contains it; and within it is a divinely authorized image of the celestial world which contains the sublunary world. The inner sanctuary, finally, localizes the supercelestial world which contains them all. The centre of this microcosmic structure thus coincides with the circumference of the macrocosm; a spatial minimum coincides with the spatial maximum.

What this structure does is to locate and enclose a divine centre which, according to the Hermetic paradox, occupies no single place: in so doing, this structure defines itself as a centre of spiritual authority and power - or rather, as the centre of such power on earth. This centre, this divine minimum-maximum, is accessible to humans in a startlingly immediate manner. Pico writes that the rending, at the moment of Christ's death, of that veil in the temple which concealed the Holy of Holies signified "that the approach to the kingdom of God now lay open for men, the approach to God himself, who flies above the cheribim, the approach closed off by the laws of justice from the beginning because of the sin of the first father."29 What he means by this becomes clear shortly afterwards when he writes that there is, in addition to the three worlds imaged by the tabernacle of Moses, "a fourth world in which are found all those things that are in the rest." 30 This fourth world is man, the microcosm, of whom Pico declared in his famous Oration that he is free either to degenerate from his middle state into lower forms of life or to be reborn into a heavenly form. He shall, moreover, 


\section{0 / Renaissance and Reformation}

surpass all beings, even the angels, "if, happy in the lot of no created thing, he withdraws into the centre of his own unity" - for there his spirit will be made "one with God, in the solitary darkness of God, who is set above all things...." 31

This transcendental self, which thus incorporates the beginning and end of philosophical inquiry, is also present, if less glamorously so, in the works of Cusanus, who writes, for example, that "Sola intellectualis natura habet in se principia...." 32 From here it is no great distance to another kind of solitary darkness, that of the famous poêle into which Descartes retreated in November 1619, and to another kind of psychological introversion, which is also a search for a centre of sorts: "Car de ce doute universel, comme d'un point fixe et immobile, je veux faire dériver la connaissance de Dieu, celle de vous-mêmes et enfin celle de toutes les choses qui existent dans la nature." 33

At the end of his intriguing short essay on the same paradox that I have been considering, Jorge Luis Borges wrote: "It may be that universal history is the history of the different intonations given a handful of metaphors."34 This fine epigram strikes me as in certain respects problematic. The word "universal" seems to serve here in a familiar way to vaporize those material realities that it is always the first concern of the ideologue to forget or to dismiss. And yet I would not for a moment deny that throughout history the appropriation and dissemination of ruling metaphors have legitimized and thus helped to perpetuate the rule of the few over many - or that the same metaphors, duly re-shaped, have repeatedly been put to work to undo this kind of hegemony. Pico's revision of the Hermetic paradox shows how easily this metaphor could acquire implicitly political resonances. And the successive reworkings of the paradox that have been traced here may lead us to a question that is of some political relevance, if only within the disciplines concerned with textual studies.

The voice of Divine Wisdom that speaks in Pascal's Pensées to condemn the human effort to find a centre within ourselves, and to punish that effort by abandoning us to ourselves in a universe without centre or limit, itself speaks from a different kind of centre. It is the voice of what Jacques Derrida calls "le signifié central, originaire ou transcendantal," the centre that commands the structure, while at the same time escaping from its structurality: "C'est pourquoi, pour une pensée classique de la structure, le centre peut être dit, paradoxalement, dans la structure et hors de la structure. Il est au centre de la totalité et pourtant, puisque le centre ne lui appartient pas, 
la totalité $a$ son centre ailleurs. Le centre n'est pas le centre." ${ }^{35}$ Derrida observes, as one feature of that age that has witnessed "l'invasion structuraliste," and as an immediate consequence of thinking "la structuralité de la structure," an effective evacuation of this centre, an absence of the transcendental signified. In the wake of this enormously influential analysis, it has become commonplace to assume that the de-centring of any discursive structure is, almost by definition, a subversive act ${ }^{36}$ But if a centred structure implies a concentration of power, whether spiritual or institutional, does its de-centring imply the dispersal of this power, or rather simply its translation into unfamiliar modes, its occultation?

\section{Université Sainte-Anne}

\section{Notes}

1 Robin Small, "Nietzsche and a Platonist Tradition of the Cosmos: Center Everywhere and Circumference Nowhere," Journal of the History of Ideas, 44 (1983), 90.

2 Ibid, 90-1, quoting from Alain de Lille's Regulae de sacra theologia, in Patrologiae cursus completus, ed. J.P. Migne, P.L, CCX (Paris, 1855), 627.

3 Ibid., 91.

$4 \mathrm{Ibid}$. Alain wrote, "In sphaera corporali centrum propter sui parvitatem vix alicubi esse perpenditur, circumferentia vero in pluribus locis esse comprehenditur. In intelligibili vero sphaera centrum ubique, circumferentia nusquam."

5 Blaise Pascal, Pensées, ed. Louis Lafuma (Paris: Éditions du Seuil, 1962), 199 (72), pp.115-6.

6 Pensées, 199 (72), p.118.

$7 \mathrm{See}$, in particular, the essay "La structure, le signe et le jeu dans le discours des sciences humaines" in Derrida's L'écriture et la différence (Paris: Éditions du Seuil, 1967).

8 Ibid., 118.

9 Pensées, 199 (72), pp.118-9. Austin's words are quoted by Hilary Putnam in "The Craving for Objectivity," New Literary History, 15 (1984), 230.

10 De docta ignorantia, Ilxi, in Nicolai Cusae Candinalis Opera (Paris, 1514; facsimile rpt. Frankfurt/Main: Minerva, 1962), vol. 1, fol.xxi:

...aliquid machinam mundanam habere, aut istam terram sensibilem, aut aerem, vel ignem, vel aliud quodcunque pro centro fixo \& immobili variis motibus orbium consideratis: est impossibile. Non devenitur enim in motu ad minimum simpliciter puta fixum centrum: quia minimum cum maximo coincidere necesse est. Centrum igitur mundi coincideret cum circumferentia. Non habet igitur mundus circumferentiam. Nam si centrum haberet: haberet \& circumferentiam. Et sic intra se haberet suum initium \& finem: \& esset ad aliquid aliud ipse mundus terminatus, \& extra mundum esset aliud \& locus: quae omnia veritate carent. Cum igitur non sit possibile mundum claudi intra centrum corporale \& circumferentiam: non intelligitur mundus, cuius centrum \& circumferentia sunt deus. Et cum hic non sit mundus infinitus: tamen non potest concipi finitus cum terminis careat intra quos claudatur. Terra igitur quae centrum esse nequit... Neque etiam est ipsum mundi centrum plus intra terram quam extra. Neque etiam terra ista, neque aliqua sphera habet centrum. Nam cum centrum sit punctus aequedistans circumferentiae, \& non sit possibile verissimam spheram aut circulum esse quin verior dari possit: manifestum est non posse dari centrum quin verius etiam dari possit, atque praecisius. Aequedistantia praecisa ad diversa extra deum: reperibilis non est. Quia ipse 


\section{2 / Renaissance and Reformation}

solus est infinita aequalitas. Qui igitur est centrum mundi scilicet deus benedictus: ille est centrum terrae, \& omnium spherarum, atque omnium quae in mundo sunt, qui est simul omnium circumferentia infinita.

11 This fact has been remarked upon by Karsten Harries in "The Infinite Sphere: Comments on the History of a Metaphor," Journal of the History of Philosophy, 13 (1975), 5.

12 De docta ignorantia, I.i; and see Ernst Cassirer, The Individual and the Cosmos in Renaissance Philosophy, tr. Mario Domandi (Philadelphia: University of Philadelphia Press, 1972), pp.10-24.

13 Pensées, 201 (206), p.122.

14 De docta ignorantia, II.xi; Opera, vol. 1, fol.xxi (the Latin text is given in note 10 above).

15 De mente (Idiotae liber III), cap. ix; Opera, vol. 1, fol.lxxxix: "Secundum mentis considerationem: continuum dividitur in semper divisibile, \& multitudo crescit in infinitum. Sed actu dividendo: ad partem actu indivisibilem devenitur, quam atomum apello. Est enim atomus: quantitas ob sui parvitatem actu indivisibilis. Sic etiam mentis consideratione multitudo non habet finem: quae tamen actu terminata est. Rerum namque omnium multitudo: sub determinato quodam numero cadit, licet nobis incognito."

16 De mente, cap. ix. fol.lxxxix: "Est enim unum \& idem punctus in omnibus atomis: sicut una \& eadem albedo in omnibus albis." Cap. vii, fol.lxxxvii: "\& hoc modo in simplicitate sua, omnia intuetur: sicut si in puncto omnem magnitudinem, $\&$ in centro circulum."

17 Giordano Bruno, Cause, Principle and Unity, tr. Jack Lindsay (London: Background Books, 1962), pp.137, 139.

18 De mente, cap. vi; Opera, vol. 1, fol.lxxxvv: "PHILOSOPHUS: Nonne sine nostrae mentis consideratione: est rerum pluralitas? IDIOTA: Est: sed a mente aeterna. Unde sicut quo ad deum, rerum pluralitas est a mente divina: ita quo ad nos rerum pluralitas est a nostra mente. Nam sola mens numerat. Sublata mente: numerus discretus non est."

19 Paul-Henri Michel, The Cosmology of Giondano Bruno, tr. R.E.W. Maddison (Paris, London, Ithaca: Hermann, Methuen, Cornell Univ. Press, 1973), p.47.

20 Cassirer, The Individual and the Cosmos, p.28.

21 Pensées, 149 (430), p.100.

22 De mente, cap. vi, fol.lxxxvv: "cum praecisio quidditatis cuiuscumque rei sit per nos inattingibilis aliter quam in aenigmate vel figura."

23 De mente, cap. ix, fol.lxxxixv: "Nam mens est viva mensura: quae mensurando alia, sui capacitatem attingit. Omnia enim agit: ut se cognoscat. Sed sui mensuram in omnibus quaerens: non invenit, nisi ubi sunt omnia unum. Ibi est veritas praecisionis eius: quia ibi exemplar eius adaequatum."

24 Descartes, "Méditation seconde," in Oeuvres philosophiques, ed. F. Alquié (Paris: Gamier, 1963-73 ), II, 414: "Archimède, pour tirer le globe terrestre de sa place et le transporter en un autre lieu, ne demandait rien qu'un point qui fût fixe et assuré. Ainsi j’aurai droit de concevoir de hautes espérances, si je suis assez heureux pour trouver seulement une chose qui soit certaine et indubitable."

25 Excitationum, V, ex sermone "Pax hominibus bonae voluntatis," Opera, vol. 2, fol. lxxxix. The same passage (fol.lxxxviiiv) contains an interesting recurrence of the centre-circumference paradox.

26 Marsilio Ficino, The "Philebus" Commentary, ed. and tr., Michael J.B. Allen (Berkeley and London: Univ. of California Press, 1975), cap. xx, 203: "Anima insuper cum in aliarum disciplinis instructa est, naturalem vim recuperans, se ipsam generat in se ipsa. Nam se cognoscendo totam sui naturam in se ipsa figurat, idque mens efficit multo melius, quia enim in ea prima cognitio est, in ea est perfectissima, proxima igitur cognito."

27 See Cassirer, 40. The microcosm motif (explicit in De docta ignorantia, III.iii) is implicit throughout the arguments of De mente: see in particular Chapters 2 to 5, and 7. 
28 Heptaplus, in Cesare Vasoli, ed., Giovanni Pico della Mirandola, Gian Francesco Pico, Opera omnia (1557-1573; facsimile rpt. Hildesheim: Georg Olms, 1969), vol. 1, "Ad lectorem praefatio," sig. A3r-v.

29 Ibid, sig. A3v: "Nam quoniam nobis ad mundum supercoelestem ad angelorum consortium, reserata est via per Christi crucem \& sanguinem, idcirco illo occumbente scissum est velum templi, quo sancta sanctorum, per quae angelicum diximus mundum significari, ab aliis partibus discludebantur. Quod fuit indicio patere iam aditum homini ad Dei regnum, ad Deum ipsum, qui volat super cherubin, aditum ab initio ob peccatum primi parentis iustitiae legibus occlusum."

$30 \mathrm{Ibid}$., sig. A4v: "Est autem praeter tres quos narravimus quartus alius mundus in quo \& ea omnia inveniantur quae sunt in reliquis, hic ipse est homo...."

31 De hominis dignitate oratio, Opera, sig. Dd2: "Nascenti homini omnifaria semina, \& omnigenae vitae germina indidit pater. Quae quisque excoluerit, illa adolescent, \& fructos suos ferent in illo. Si vegetalia, planta fiet. Si sensualia, obbrutescet. Si rationalia, coeleste evadet animal. Si intellectualia, angelus erit \& Dei filius. Et si nulla creaturarum sorte contentus, in unitatis centrum suae se receperit, unus cum Deo spiritus factus, in solitaria patris caligine qui est super omnia constitutus, omnibus antestabit."

32 Cusanus, Excitationum, V, Ex sermone "Pax hominibus bonae voluntatis," Opera, vol. 2, fol.lxxxix. On Cusanus and the pure or transcendental subject, see Karsten Harries, "The Infinite Sphere," pp.5-15.

33 Descartes, La recherche de la vérité par la lumière naturelle, in Oeuvres philosophiques, ed. Alquié, vol. 2, 1122.

34 Borges, "The Fearful Sphere of Pascal," Labyrinths, ed. DA. Yates and J.E. Irby (Penguin, 1974), p.227.

35 Derrida, "La structure, le signe et le jeu," in L'écriture et la différence, pp.410-11.

36 See, for example, Jonathan Dollimore, Radical Tragedy: Religion, Ideology and Power in the Drama of Shakespeare and his Contemporaries (Brighton and Chicago: Harvester Press and Univ. of Chicago Press, 1984), pp.49-50, 153 ff. 